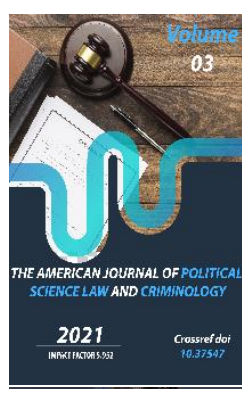

\title{
Objective Signs Of The Conclusion Of Transactions Contrary To The Interests Of The Republic Of Uzbekistan
}

\author{
Shodmon Alisherovich Ashurov \\ Master Student Of Tashkent, State Law University, Uzbekistan
}

Copyright: Original

content from this work may be used under the terms of the creative commons attributes 4.0 licence.

\section{ABSTRACT}

This article provides a legal analysis of the corpus delicti of transactions, contrary to the interests of the Republic of Uzbekistan, and examines in detail the objective signs. In particular, such concepts as object, subject, interests, types of criminal object, damage and its types are analyzed. The opinions and approaches of foreign and domestic scientists on this matter were also taken into account. In addition, it is noted that the public danger of making transactions contrary to the interests of the Republic of Uzbekistan lies in the fact that when committing a crime, not only the rights of individuals are violated, but also damage to society as a whole. In addition, during the transitional period of the life of society and the state, the number of crimes of this kind grows rapidly and can cause significant damage to the economic foundations of the state. The final section contains suggestions and recommendations for eliminating negative factors.

\section{KEYWORDS}

Crime, socially dangerous, object of crime, object of crime, transaction, interest, damage

\section{INTRODUCTION}

In recent years, there has been a significant increase in the dynamics of crimes against the foundations of the economy. There is not a single state or society that does not suffer from a crime against the foundations of the economy. Therefore, the issues of this struggle 
are regulated on the basis of international documents and national legislation. Although the act is not the only criterion for inclusion in the list of crimes against the fundamentals of the economy, it has some common features. For example, causing harm, contractual discipline, guarantees of property rights, the procedure for the formation of economic resources established in the republic, social relations that ensure the activities of enterprises or other structures carrying out entrepreneurial activities, established by law, their own charter, etc.

The Constitution and legislative acts of the Republic of Uzbekistan establish that the basis of the economy of Uzbekistan is property in various forms, the state guarantees freedom of economic activity, entrepreneurship and labor, equality and equal legal protection of all forms of ownership, taking into account the supremacy of consumer rights.

\section{THE MAIN RESULTS AND FINDINGS}

The Criminal Code, adopted on September 22, 1994, for the first time established responsibility for concluding transactions contrary to the interests of the Republic of Uzbekistan, this provision consisted of two parts. The crime of concluding transactions contrary to the interests of the Republic of Uzbekistan is contained in Chapter 12, Article 175 of the Criminal Code "Crimes against the foundations of the economy".

Part one of this norm establishes the responsibility of an official of a state body, enterprise, institution, organization, public association, regardless of the form of ownership, for concluding a deliberately unfavorable transaction that entailed causing significant damage to the interests of the republic. The second part of this provision establishes responsibility for the commission of these actions again, by a group of persons by prior conspiracy and causing significant damage.

In our opinion, the clarification of the object of the crime of concluding transactions contrary to the interests of the Republic of Uzbekistan is important not only in the systematization of the criminal law, but also in determining the nature and degree of social danger of the crime, the correct qualification of the act.

The general object of this crime is social relations protected by criminal law.

The conclusion of transactions contrary to the interests of the Republic of Uzbekistan is a crime that is objectively unprofitable, including the conclusion of transactions that entailed the import into the territory of the Republic of Uzbekistan of previously used, physically worn out, obsolete or inadequate equipment or technologies, as well as their installation and introduction, which caused significant damage to the interests of the Republic of Uzbekistan., the same is expressed in the issuance by an official of an authorized state body or other organization of an expert opinion or other document that served as the reason for the conclusion of such a transaction.

The legal analysis of any crime means the analysis of the corpus delicti, that is, the objective and subjective signs of a crime. Objective signs of a crime is a concept that covers the object and objective side of the crime.

The object of the crime is social relations protected by the criminal law; as a result of a 
criminal act, these social relations are infringed upon and harm is caused [1].

The object of the crime is not any public relation, but only the public relation protected by the criminal law. In this regard, M.Kh. Rustambaev notes that the object of the crime is public relations, which in the aggregate are a purely social category, the highest priority and socially significant, protected by the criminal law, as a result of the commission of a crime they are harmed or threatened with harm [2] ...

As you know, when defining the concept of an object of a crime, one should proceed from the principle "the question of the nature and direction of harm [3] caused or threatening to be inflicted by a criminal offense should be taken as a basis," scientists consider the object of a crime: social relations [4], personality 5], human rights [6], a certain social (legal) interest [7] or social security [8]. Based on these concepts, that the object of a crime is a public relation, that a crime directly damages social relations between members of society, the concept "Social attitude - object of crime" is perceived by many researchers as a whole.

Another scientist believes that the object of the crime as an element of the corpus delicti has a slightly different content than, for example, the object of criminal law protection. In this case, it includes legal signs of an encroachment in its material or relative terms, signs of the consequences of an encroachment on an object [9].

If the object of a criminal offense is defined as an element of the corpus delicti, then the definition that some authors cite as the most general (abstract) definition, in our opinion, is appropriate. The object of a crime is an object that the crime encroaches on, causes harm or creates a threat of harm (may cause harm).

The crime of concluding transactions contrary to the interests of the Republic of Uzbekistan consists of four parts, the direct object of the crime is public relations that provide the foundations of the economy of the Republic of Uzbekistan.

As you know, the object of the crime and the object of the crime are not the same thing. It should be borne in mind that the subject is not always a permanent sign of a crime. The Criminal Code, again, provides for such compositions, the subject of which is difficult to indicate, since the subject is understood as something material (visible to the naked eye, measurable, possessing qualitative and distinctive features).

According to E.Kh. Norbutaev's concept, "interest" as an object of crime, the category of "interests" is at a higher level in relation to social relations arising between the subjects, but is not always regulated by the norms of law.

"Interest" as an integral element of the subjects of legal relations is wealth and interest, expressed in the law of the state and the individual [10]. In some foreign criminal law systems, the term "object of crime" is not used at all, instead such concepts as "legal interest", "protected legal interest" and others are used [11].

Thus, the category of interest "determines the content of the object of the crime and" ... it is appropriate for any aspect of social life and human activity. "We believe that this concept has a future, it deserves to be considered as an object of research and development. But one 
cannot but agree with the author's opinion that "object of a crime" is a term that does not correspond to criminal law. This term fully and comprehensively characterizes a crime, since a crime cannot do without it.

In order to recognize the act of a person as a crime, it is necessary that its composition exists. The corpus delicti consists of four elements, which include: the object of the crime, the objective side of the crime. the subject of the crime, the subjective side of the crime.

In the theory of criminal law, the objective side of a crime is defined as follows: the objective side of a crime is understood as signs that characterize the external circumstances of a socially dangerous act or inaction committed against an object protected by criminal law [12].

The objective side of the crime is a necessary element of the corpus delicti, which is of great importance as a basis for criminal liability. The disposition of the articles of the Special Part of the Criminal Code indicates the objective signs of each crime, that is, crimes differ from each other mainly in the mode of action or inaction, the criminal outcome, the circumstances of the crime and other aspects. Consequently, the objective side of the crime is essential within the scope of the corpus delicti and helps in determining which crime was committed.

It should be noted that some scholars believe [13] that sections and chapters of the criminal law should be drawn up in accordance with the special and generic objects of the crime. Some say [14] that sections of the Criminal Code should be drawn up on a special object, a chapter on a generic object, and an article on a direct object. In this regard, the opinion of A.S. Yakubov is of great importance that "to build a system of the Special Part of the Criminal Code, it is necessary to have a special object basis" [15].

According to NI Vetrov [16], the norms of the Special Part of the Criminal Code are systematized based on the special object of the act. Each section or even chapter has its own special object, he says. In our opinion, the legislator attributed crimes similar in a special object to the sections of the special part of the Criminal Code, and crimes similar in a generic object to chapters.

Unlike B.S. Nikiforov, who criticized the existing classification of objects mainly due to the inconsistency of terminology and definitions of concepts, M.I. Fedorov proposed to abandon the concept of a common object of a crime. The scientist believed that there is no common object of crime in nature. Thus, M.I. Fedorov believes that only the concept of a common object of a crime can exist. However, rejecting this point of view, it should be specially noted that any crime primarily damages common objects protected by criminal law, and in this regard, these relations are recognized as common objects of crime.

It is noted that the social danger of concluding transactions contrary to the interests of the Republic of Uzbekistan lies in the fact that when committing a crime, not only the rights of individuals are violated, but also damage to society as a whole. In addition, during the transition period of the life of society and the state, the number of crimes of this kind grows rapidly and can cause significant damage to the economic foundations of the state. 
Here is an analysis of the object of the crime provided for in Article 175 of the Criminal Code, in accordance with the theoretical provisions set forth above.

The object of the crime of concluding transactions contrary to the interests of the Republic of Uzbekistan is the foundations of the economy of the Republic of Uzbekistan, the economic system of the Republic of Uzbekistan, when committing a crime under Article 175 of the Criminal Code, the interests of the Republic of Uzbekistan are damaged.

The interests of the Republic of Uzbekistan are recognized as the creation of an effective market economy, the protection of property and material relations, national values, and the achievement of commodity integrity. These interests are reflected and enshrined in legislation, which establishes special requirements for the conclusion of transactions, including this equally applies to the conduct of trade operations and to foreign economic transactions concluded.

The crime of concluding transactions contrary to the interests of the Republic of Uzbekistan from the objective side is expressed in the conclusion of transactions that caused significant damage to the interests of the republic, were unprofitable.

In accordance with Article 101 of the Civil Code of the Republic of Uzbekistan, actions aimed at establishing, changing or terminating the civil rights and obligations of citizens and legal entities are a transaction. There are unilateral, bilateral or multilateral types of transactions. The offense provided for in article

175 of the Criminal Code, is made by concluding a bilateral or multilateral transaction- agreement. Also, this crime can be committed by concluding unilateral transactions.

Also, transactions can be conditional (ie, transactions with deferral and cancellation), compensated and gratuitous, real and consensual, casual (controversial) and abstract [17]. The form of the transaction made does not affect the qualification of the act, but should be taken into account by the court when imposing a punishment on the guilty person.

In accordance with Articles 105-112 of the Civil Code of the Republic of Uzbekistan, the conclusion of such a transaction is the expression of the will of the parties under all the terms of the transaction in the manner prescribed by law, and if these two conditions are met, the transaction is considered concluded between the parties:

- The will must be expressed in accordance with all the terms of the transaction;

- The form of facial expression must meet all the requirements for transactions.

The crime of concluding transactions contrary to the interests of the Republic of Uzbekistan is considered completed from the moment of causing damage to the interests of the republic on a large scale. If the expression of will is expressed in a different form than prescribed by law, and the requirement to register a transaction (for example, real estate purchase and sale agreements) is not met, it cannot be recognized as concluded, since it is not considered valid, that is, it does not generate, does not change and does not entail termination of civil rights and obligations. In this case, the actions of the perpetrator are qualified as an attempt to commit a crime 
under Part 2 of Article 25 of the Criminal Code and Part 1 of Article 175 of the Criminal Code (in the absence of aggravating circumstances).

A significant sign of the objective side of this crime is the infliction of significant damage to the interests of the republic as a result of the conclusion of a transaction that is contrary to the interests of the Republic of Uzbekistan. A large amount represents an amount from three hundred to five hundred times the minimum wage.

The amount of damage in each case is determined by the body of inquiry or the court and is determined [18] according to the content of the article:

- Actual damage, that is, costs that the state will incur or incur in the future in order to restore its violated interests;

- Lost profit [19], that is, profit not received from civil turnover [20].

When determining the amount of loss [21], the loss of profit due to the conclusion of a transaction that is contrary to the interests of the Republic of Uzbekistan is not taken into account.

Clause 11 of the Resolution of the Plenum of the Supreme Court of the Republic of Uzbekistan dated April 17, 1998 No. 11 "On some issues that have arisen in judicial practice in cases of crimes in the economic sphere" states that the conclusion of a transaction contrary to the interests of the Republic of Uzbekistan should be understood as the actions of an official who knowingly knew that the deal he was making was unfavorable to the interests of the Republic of Uzbekistan (for example, the prices for the supply of products were clearly understated, or the prices for the receipt of products, their transportation, etc. were clearly overestimated). At the same time, large or especially large damage caused to the interests of the republic should always be established as the consequences of the crime provided for in Article 175 of the Criminal Code. The amount of this damage, whether large or particularly large, must be argued by the investigating authority [21] and the court [22] in each specific case.

The number of transactions concluded contrary to the interests of the Republic of Uzbekistan may, for example, also include the facts [23] of the sale of state property to other owners at significantly reduced prices. The conclusion of the court that the transaction contradicted [24] the interests of the state can be made taking into account the expert opinion.

When investigating [25] and judicial consideration of cases of this category, it is imperative to find out the reasons and conditions [26] contributing to the commission of these crimes. If, however, selfish or other base motives of the perpetrator are established when concluding these transactions, such actions should also be qualified under the articles of the Criminal Code, which provide for liability for relevant crimes committed with the use of power or official position.

In this regard, in our opinion, it seems necessary to expand the incentive norms in the system of criminal punishments today on the following grounds:

Firstly, the widespread use of incentive norms in the criminal justice system is an important 
criterion for ensuring human rights in criminal law;

Secondly, the expansion of incentive norms is, in fact, an important component of the liberalization of criminal law;

Third, the widespread use of incentive norms is also acceptable to the state for several reasons. This optimality is expressed in reducing the costs of the state budget in economic terms, and in social terms, in preventing the negative impact of the crime situation in prisons on convicts, etc.

Fourthly, the widespread introduction of incentive norms in criminal law is consistent with generally recognized norms and principles of international law, which, in turn, serves to ensure the consistency of national criminal law policy with international legal policy.

Based on the foregoing, in accordance with part 4 of Article 175 of the Criminal Code, a person is released from punishment in the event of compensation for material damage in three times.

\section{CONCLUSION}

In conclusion, it should be noted that the reforms carried out in our country in the field of liberalizing criminal punishment for crimes against the foundations of the economy and expanding the scope of application of incentive norms:

Firstly, the widespread use of punishments alternative to imprisonment in the system of criminal punishment requires improvement;

Secondly, the expansion of alternative types of punishment, which are an important component of the liberalization of criminal legislation;

Third, the wider use of those types of punishments when imposing punishment, which make it possible to morally correct a person without isolating him from society;

Fourthly, it seems appropriate to bring the widespread introduction of alternative types of punishment into national legislation in line with generally recognized norms and principles of international law and to continue work in other humane and fair directions.

\section{REFERENCES}

1. Usmonaliev M., Bakunov P. Criminal law. General part: Textbook. Tashkent: Nasaf, 2010. - P. 132.).

2. Rustambaev M.Kh. Course of criminal law of the Republic of Uzbekistan. II volume. A common part. The doctrine of crime: textbook. - Tashkent: IIm Zie, 2010. - P. 140.

3. Novoselov G.P. Teaching about the object of the attack. Methodological aspects. - M.: Norma, 2001. - P. 45.

4. Usmonaliev M. Criminal law. A common part. Textbook for higher educational institutions. - Tashkent: Generation of the new century, 2005. P. 152; Rustamboev M.Kh. Criminal law (general part). Textbook for higher educational institutions. - Tashkent: TDII, 2006. - P. 125.; Criminal law of Russia. Part two: textbook for universities / OTV. Ed. prof. L. L. Kruglikov - M.: Beck, 1999. -P. 117-119; Russian criminal law. In two volumes. Most of. / Ed. N. prof. Raroga A.I. - M.: 
Jurist, 2001.T.1. - P. 103-105; Sharapov R.D. Physical abuse in criminal law. SPb: Legal Center Press, 2001. - P. 160167.

5. Kudryavtsev V.N. On the question of the relationship between the subject and the subject of the crime. // Soviet state and law. - Moscow, 1951. - No. 8. P. 58-59. Novoselov G.P. The doctrine of the object of the crime. Methodological aspects. - M.: Norma, 2001. - P. 60.

6. Krasikov A.N. Criminal law protection of human rights and freedoms in Russia. - Saratov, 1996. -P. 2-3.

7. Norbutaev E.Kh. Problems of the effectiveness of legal measures to combat crime (theory and practice): Author's abstract. dis. ... doct. jurid. sciences. - Tashkent, 1991. - P. 32.; A.V. Naumov Criminal law. A common part. Lecture course. - M., 1996. -P. 146-151.

8. Krylova E. Serebrennikova, A.V. Criminal law of modern foreign countries (England, USA, France, Germany): textbook. - M., 1997. -P. 58-

73.

9. Criminal law of Russia. Textbook for universities. In 2 volumes. V. 1. General part / Otv. ed. Doctor of Law A. N. Ignatov and Doctor of Law Yu.A. Krasikov. - M., 1998. - P. 101

10. Norbutaev E.Kh. Criminal law and its effectiveness. Toshkent. "Mennat" 2002 - P. 73.

11. Krylova E., Serebrennikova A.V. Criminal law of modern foreign countries (England, USA, France, Germany): Textbook. - M., 1997. - P. 5873.
12. Criminal law. General part: Textbook. / A.S. Yakubov, R. Kabulov and others Tashkent. Academy of the Ministry of Internal Affairs of the Republic of Uzbekistan, 2009. - P. 374

13. Criminal law of the Russian Federation. A special part / BV Zdravomyslov, VF Karaulov and others; Ed. prof. B.V. Zdravomyslova. - M.: Jurist, 2000. - P. 18.

14. Criminal law of the Russian Federation. General part / S.V. Afinogenov, L.D. Ermakova and others; Ed. prof. B.V. Zdravomyslova. - M.: Jurist, 1999. - P. 112-113.

15. Yakubov A.S. Preconditions for criminal law reform in the Republic of Uzbekistan. - T., 1994. - P. 47.

16. Vetrov N.I. Criminal law. A common part. - M.: Unity, 1999. - P. 114.

17. Large legal dictionary. / Under. ed. A.Ya. Sukharev, V.E. Krutskikh. (2nd edition, revised and enlarged). - $M$.: INFRA-M. 2000, P. 548.

18. Collection of decisions of the Plenum of the Supreme Court of the Republic of Uzbekistan. 1991-1998. Volume 2. P. 154.

19. Tadjibaeva Albina. Some Issues of The Defense Function in Criminal Proceedings in The Appointment of Forensic Psychiatric Examination in The Republic of Uzbekistan. Jour of Adv Research in Dynamical \& Control Systems, Vol. 11, Issue-07, 2019.

20. Tadjibaeva Albina Yuldashbaevna. Theoretical analysis of criminal procedural functions. Electronic Journal of Legal Research 3 (SPECIAL 2). -p.319-326 https://tadqiqot.uz/wp- 
content/uploads/2020/04/huquq-2020-

SI/huquq-2020-SI-3.pdf.

21. Tulaganova Gulchehra, Tadjibaeva Albina. The Role and Importance of Anti-Corruption Researching International Journal of Innovative Technology and Exploring Engineering (IJITEE) ISSN: 2278-3075, Volume-9, Issue-1, November 2019 https: // doi: 10.35940 / ijitee.A9159.119119.

22. $T$ Albina, The role of a lawyer in ensuring the protective function of the Republic of Uzbekistan in criminal proceedings. European Journal of Molecular \& Clinical Medicine 7 (2), 2162-2168.

23. Tulaganova G. Z., Tadjibaeva A. Yu. GUARANTEE OF ENSURING TRUE INDEPENDENCE OF JUDGES // JURNAL PRAVOVYX ISLEDOVANIY. - 2021. - T. 6. - №. 3 .

24. Tadjibaeva A. Yu. FUNCTIONS OF THE CRIMINAL PROCESS AS AREA OF PROCEDURAL ACTIVITY // Electronic Journal of Legal Research. - 2020. - T. 5. - No. 1)

25. T Albina. ESSENCE AND CONTENT OF THE JUDICIARY. MODERN SCIENTIFIC CHALLENGES AND TRENDS, 2021, P.137.

26. Fazilov F.M. COVID-19 and the general concept of the determinants of legalization of proceeds from crime "Yuridik fanlar akhborotnomasi Bulletin of legal sciences - Review of law sciences" (2020, special issue) p.198-203) https://cyberleninka.ru/article/n/covid19-i-obschee-ponyatie-determinantlegalizatsii-dohodov-poluchennyh-otprestupnoy-deyatelnosti. 